University of Nebraska - Lincoln

DigitalCommons@University of Nebraska - Lincoln

Influenza Immunization and Subsequent Diagnoses of Group A Streptococcus-IIlnesses among U.S. Army Trainees, 2002-2006

\author{
Seung-eun Lee \\ Angelia Eick \\ Michael S. Bloom \\ John F. Brundage
}

Armed Forces Health Surveillance Center-provisional, U.S. Army Center for Health Promotion and Preventive Medicine, 2900 Linden Lane, Suite 200, Silver Spring, MD 20910, United States

Follow this and additional works at: https://digitalcommons.unl.edu/usarmyresearch

Part of the Operations Research, Systems Engineering and Industrial Engineering Commons

Lee, Seung-eun; Eick, Angelia; Bloom, Michael S.; and Brundage, John F., "Influenza Immunization and Subsequent Diagnoses of Group A Streptococcus-IIInesses among U.S. Army Trainees, 2002-2006" (2008). US Army Research. 44.

https://digitalcommons.unl.edu/usarmyresearch/44

This Article is brought to you for free and open access by the U.S. Department of Defense at DigitalCommons@University of Nebraska - Lincoln. It has been accepted for inclusion in US Army Research by an authorized administrator of DigitalCommons@University of Nebraska - Lincoln. 


\title{
Influenza immunization and subsequent diagnoses of group A streptococcus-illnesses among U.S. Army trainees, 2002-2006
}

\author{
Seung-eun Lee*, Angelia Eick, Michael S. Bloom ${ }^{1}$, John F. Brundage \\ Armed Forces Health Surveillance Center-provisional, U.S. Army Center for Health Promotion and Preventive Medicine, 2900 Linden Lane, Suite 200,
} Silver Spring, MD 20910, United States

\section{A R T I C L E I N F O}

\section{Article history:}

Received 4 January 2008

Received in revised form 9 April 2008

Accepted 17 April 2008

Available online 7 May 2008

\section{Keywords:}

Influenza

Influenza vaccine

Group A streptococcus

Viral-bacterial interaction

\begin{abstract}
A B S T R A C T
To assess the association between influenza immunization and subsequent diagnosis of group A streptococcus (GAS)-illness in Army recruits during influenza seasons 2002-2006. A case-control study was employed with cases as trainees with outpatient GAS diagnosis (ICD-9-CM codes: 034.0, 035, 038.0, 041.01, $320.2,390-392,482.31$ ) during the influenza season, and controls as trainees with no outpatient GAS diagnosis during the influenza season. Primary exposure was influenza immunization during 1st September to 30th April of each season. Estimated protective effects of influenza immunization against GAS-illness ranged from $50 \%$ to $77 \%$. A strong protective effect was suggested for Army trainee influenza immunization on the diagnosis of GAS-illness.
\end{abstract}

(c) 2008 Elsevier Ltd. All rights reserved.

\section{Introduction}

Group A streptococcus (GAS) infections are often asymptomatic; and of those that are clinically significant, most are expressed as acute, febrile tonsillo-pharyngitis (i.e., strep throat) that is transiently debilitating [1]. However, some virulent GAS strains cause invasive diseases that can be severe (e.g., peritonsillar abscess) and even life threatening (e.g., pneumonia, necrotizing fasciitis, toxic shock). Finally, some "rheumatogenic" strains of GAS have delayed clinical effects that are acutely debilitating (e.g., acute rheumatic fever) and often chronically disabling (e.g., valvular heart disease) [2-4].

Since the 1950s, at various military training installations, benzathine penicillin $\mathrm{G}$ (BPG) has been given to non-allergic trainees before they begin recruit training. This process of tandem prophylaxis (administering prophylaxis to new incoming recruits) is designed to prevent the introduction of virulent strains of GAS into recruit camps and to protect new recruits from acquiring GAS infections during the first few weeks of training $[3,4]$. Although BPG is effective in reducing the risk for GAS infection, continued outbreaks highlight the need for additional preventive measures.

\footnotetext{
* Corresponding author. Tel.: +1 301319 3268; fax: +1 3013197620

E-mail address: seungeun.lee@us.army.mil (S.-e. Lee).

1 Current address: SUNY Albany, School of Public Health, Department of Environmental Health Sciences, 1 University Place, Room \#153, Rensselaer, NY 12144, United States.
}

New military recruits are a sample of the young adult population of the United States and its territories who enter the training installation on a daily basis. Therefore, numerous and varied respiratory pathogens are continuously 'seeded' into, and co-circulate in, recruit populations, particularly during the fall-winter seasons. co-circulating respiratory pathogens may interact through many mechanisms. The most studied and best-documented interactions are between influenza and bacterial respiratory pathogens, including GAS [5-8]. Not surprisingly, during past influenza pandemics, streptococcal pneumonias caused a substantial number of deaths, including among young adults [5].

To counter the threats of influenza and GAS-related diseases, all new recruits are immunized with the current year's influenza vaccine at all military installations, and routinely administered BPG prophylaxis against GAS at Forts Benning, Leonard Wood, and Sill, beginning basic combat training (BCT). The aim of the current study was to assess the effects, if any, of influenza immunization on GAS-related illnesses, in perennially high risk settings and seasons, using routinely collected surveillance data. To address this aim, a case-control study design was employed, in which streptococcal illnesses diagnosed among U.S. Army trainees were assessed in relation to their records of influenza immunization status in one of the four recent influenza seasons.

\section{Methods}

The surveillance period encompassed four influenza seasons defined as 1st September to 30th April of 2002-2003, 2003-2004, 
2004-2005, and 2005-2006. The surveillance population included all active component members of the U.S. Army who entered as trainees anytime during the surveillance period at a BCT site: Fort (Ft.) Benning, GA; Ft. Jackson, SC; Ft. Knox, KY; Ft. Leonard Wood, MO; or Ft. Sill, OK. Trainees were followed from entry into training until 30th April of any given year. All study data were captured from the Defense Management Surveillance System (DMSS), a public health surveillance database that includes routinely collected data on all medical encounters at military treatment facilities, as well as demographic data for military service members [9].

A case was defined as the occurrence of at least one outpatient diagnosis of a GAS-related illness (ICD-9-CM codes: 034.0, 035, 038.0, 041.01, 320.2, 390-392, 482.31), a minimum of 30 days (the estimated protective effect from a single dose of BPG) after the start of BCT [10]. The latter criterion was employed to avoid bias that may be introduced into the study results due to the selective administration of BPG at Fts. Benning, Leonard Wood, and Sill. To note, other evidence suggests inadequate serum levels of BPG after 14 days of administration [11]. However, identical results were produced when repeating our analysis using a shorter window of 14 days. Each case was matched to a maximum of four trainees with no outpatient GAS-related illness diagnosis (i.e., 'controls'), by unit identification code (UIC), a code specific to each BCT site and individual training unit.

Exposure was defined as the receipt, or the lack thereof, of an influenza immunization a minimum of 14 days (the estimated time to development of protective antibodies after immunization) prior to the date of diagnosis [12]. As multiple vaccines are typically administered to all new recruits, trainees with no documented vaccinations were excluded from the study to minimize misclas- sification due to missing records ( $n=5,400,3.7 \%$ of records). To note, BCT is a 9-week training program and is the recruits' first encounter at a military installation/post as a military service member. An influenza immunization administered to a recruit would have occurred at a BCT post.

Statistical analysis was performed using SAS version 9.1.3 (SAS Institute, Cary, NC). Cases and controls were assessed with respect to demographic/military characteristics and exposure to influenza immunization, by influenza season, using McNemar's $\chi^{2}$ tests. Conditional logistic regression, matched by UIC, was used to evaluate the effect of influenza immunization adjusted for independent predictors of GAS-illness and/or influenza vaccination reported in the literature. Covariates included age, gender, and month of entry into service (proxy for total number of recruits on post) [13-15]. $P<0.05$ for a two-tailed test was considered statistically significant.

\section{Results}

One thousand and ninety-eight GAS-illness cases and 4370 controls were identified over the 2002 through 2006 influenza seasons. Across seasons, the median of the distribution of months in which GAS-related illnesses was documented among the unexposed recruits (i.e., unimmunized), December, was several months earlier than that documented among the exposed recruits (i.e., immunized), February. Stratified by season, GAS cases had a significantly lower odds than controls to have received an influenza immunization in both crude and adjusted (i.e., for age, gender, month of entry into military service, and UIC) analyses (Table 1 ). The estimated protective effects of influenza immunization against GAS-illness ranged from 50\% (2002-2003 season) to 77\% (2005-2006 season).

Table 1

Crude and adjusted odds ratio (OR) for GAS-illness to have received influenza vaccine, by influenza season ${ }^{\mathrm{a}}$

\begin{tabular}{|c|c|c|c|c|c|}
\hline Influenza season & Influenza vaccine & GAS cases $n(\%)$ & Controls $n(\%)$ & OR $(95 \% \mathrm{CI})$ & Adjusted OR $(95 \% \mathrm{CI})^{\mathrm{b}}$ \\
\hline 2002-2003 & $\begin{array}{l}\text { Yes } \\
\text { No }\end{array}$ & $\begin{array}{l}152(53.0) \\
135(47.0)\end{array}$ & $\begin{array}{l}715(62.9) \\
421(37.1)\end{array}$ & $\begin{array}{l}0.59(0.44-0.80) \\
\text { Reference }\end{array}$ & $\begin{array}{l}0.50(0.37-0.68) \\
\text { Reference }\end{array}$ \\
\hline 2003-2004 & $\begin{array}{l}\text { Yes } \\
\text { No }\end{array}$ & $\begin{array}{r}251(72.1) \\
97(27.9)\end{array}$ & $\begin{array}{r}1215(87.9) \\
168(12.2)\end{array}$ & $\begin{array}{l}0.33(0.25-0.45) \\
\text { Reference }\end{array}$ & $\begin{array}{l}0.26(0.19-0.36) \\
\text { Reference }\end{array}$ \\
\hline 2004-2005 & $\begin{array}{l}\text { Yes } \\
\text { No }\end{array}$ & $\begin{array}{r}112(59.3) \\
77(40.7)\end{array}$ & $\begin{array}{l}633(83.7) \\
123(16.3)\end{array}$ & $\begin{array}{l}0.22(0.15-0.32) \\
\text { Reference }\end{array}$ & $\begin{array}{l}0.14(0.09-0.22) \\
\text { Reference }\end{array}$ \\
\hline 2005-2006 & $\begin{array}{l}\text { Yes } \\
\text { No }\end{array}$ & $\begin{array}{r}198(72.3) \\
76(27.7)\end{array}$ & $\begin{array}{l}971(88.7) \\
124(11.3)\end{array}$ & $\begin{array}{l}0.25(0.17-0.37) \\
\text { Reference }\end{array}$ & $\begin{array}{l}0.23(0.15-0.35) \\
\text { Reference }\end{array}$ \\
\hline
\end{tabular}

Note: CI, confidence interval; GAS, group A streptococcus; OR, odds ratio; UIC, unit identification code.

a Case defined as at least one occurrence of ICD-9-CM codes 034.0, 035, 038.0, 041.01, 320.2, 390-392, 482.31.

b Adjusted for sex, age, month of service entry, and UIC.

Table 2

Crude and adjusted odds ratio for GAS-illness over four influenza seasons ${ }^{\mathrm{a}}$

\begin{tabular}{|c|c|c|c|c|c|}
\hline Characteristic & & GAS cases $(n=1098) n(\%)$ & Controls $(n=4370) n(\%)$ & OR $(95 \% \mathrm{CI})$ & Adjusted OR $(95 \% \mathrm{CI})^{\mathrm{b}}$ \\
\hline Influenza & Yes & $713(64.9)$ & $3534(80.9)$ & $0.40(0.35-0.47)$ & $0.34(0.29-0.40)$ \\
\hline Vaccine & No & $385(35.1)$ & $836(19.1)$ & Reference & Reference \\
\hline \multirow[t]{2}{*}{ Sex } & Male & $912(83.1)$ & $3530(80.8)$ & $1.22(1.00-1.49)$ & $1.28(1.04-1.57)$ \\
\hline & Female & $186(16.9)$ & $840(19.2)$ & Reference & Reference \\
\hline \multirow[t]{4}{*}{ Age } & $17-19$ & $576(52.5)$ & $2139(48.9)$ & $1.73(1.09-2.74)$ & $1.62(1.01-2.59)$ \\
\hline & $20-24$ & $435(39.6)$ & $1667(38.2)$ & $1.67(1.05-2.66)$ & $1.54(0.96-2.48)$ \\
\hline & $25-29$ & $65(5.9)$ & $425(9.7)$ & $0.98(0.58-1.65)$ & $0.89(0.52-1.52)$ \\
\hline & $30-35$ & $22(2.0)$ & $139(3.2)$ & Reference & Reference \\
\hline Influenza & 2002-2003 & $287(26.1)$ & $1136(26.0)$ & $1.00(0.79-1.26)$ & $0.80(0.63-1.03)$ \\
\hline \multirow[t]{3}{*}{ Season } & 2003-2004 & $348(31.7)$ & $1383(31.7)$ & $1.00(0.80-1.24)$ & $1.09(0.87-1.38)$ \\
\hline & 2004-2005 & $189(17.2)$ & $756(17.3)$ & $1.00(0.78-1.28)$ & $0.92(0.71-1.19)$ \\
\hline & 2005-2006 & $274(24.9)$ & $1095(25.1)$ & Reference & Reference \\
\hline
\end{tabular}

Note: $\mathrm{CI}$, confidence interval; GAS, group A streptococcus; OR, odds ratio; UIC, unit identification code.

a Case defined as at least one occurrence of ICD-9-CM codes 034.0, 035, 038.0, 041.01, 320.2, 390-392, 482.31.

b Adjusted for sex, age, season, month of service entry, and UIC. 
Collapsed over the four influenza seasons considered (Table 2), GAS cases had a $66 \%$ lower odds of having received an influenza immunization than controls (adjusted odds ratio [aOR] 0.34; 95\% confidence interval [CI], 0.29-0.40). Approximately 65\% of all cases and $81 \%$ of all controls had documented influenza immunizations during the combine influenza seasons. Of the 1221 with no documented influenza immunization, $26(2.1 \%)$ had documented reasons for missing immunization; $15(1.2 \%)$ received medical exceptions (e.g., egg allergy), and 11 (0.9\%) did not receive immunization due to administrative orders (e.g., termination of military service). Adjusted for immunization status, and the aforementioned covariates, males had a greater odds for a GAS-illness diagnosis than females (aOR 1.28; 95\% CI, 1.04-1.57). Age was also an independent predictor for GAS-illness, with trainees younger than 25 years demonstrating nearly twice the odds for a diagnosis than those 30 years and older (aOR 1.62; 95\% CI, 1.01-2.59).

\section{Discussion}

A strong protective effect was suggested for BCT influenza immunization on the diagnosis of a GAS-illness, in a young and healthy military population (aOR $0.34 ; 95 \% \mathrm{CI}, 0.29-0.40$ ). This association was consistent across four recent influenza seasons. The results suggest that influenza immunization may decrease the odds of acquiring, and/or change the clinical expression of, GAS infections during recruit training. Epidemiologic and clinical interactions between influenza and bacterial respiratory pathogens are well documented in the literature, suggesting biologic plausibility for the measured beneficial effect of influenza immunization on GAS-illness in the current study. However, due to several study limitations, these findings must be interpreted cautiously.

The case definition employed in the current study was based on routinely kept medical surveillance records and thus the specific criteria for GAS diagnosis (i.e., clinical vs. laboratory) are unknown. The lack of laboratory confirmation may raise concern with regard to possible misclassification in that a clinician may erroneously assign a GAS diagnosis based on clinical presentation rather than diagnostic test results [16]. However, previously published work suggests that only a minority, $\sim 2 \%$, of clinicians use clinical criteria alone to diagnose GAS and this proportion may be decreasing over time with the increasing availability of highly sensitive, easy to use point-of-care tests (e.g., rapid antigen-detection test) [17,18]. Furthermore, we do not expect clinicians to differentially diagnose GAS based on a trainee's influenza immunization status (i.e., exposure). The employment of routinely reported medical administrative records (i.e., ICD-9-CM codes) introduces the possibility of case-misclassification due to data entry and miscoding errors. The use of routinely reported medical administrative records also introduces the possibility of exposure misclassification due to data entry and miscoding errors in vaccine administration. Furthermore, many of the other immunizations administered at the start of recruit training may play a role in the observed effect between influenza vaccine and GAS-related illnesses. A high prevalence of unimmunized recruits (i.e., 11-47\%) was documented during the current study. Given that U.S. Army policy dictates inoculation with the current year's influenza vaccine to all non-allergic service members, the latter prevalence may reflect incomplete or inaccuracies in reporting [19]. However, the surveillance period corresponding to the 'influenza season' employed in the current study, September through April, may have resulted in the capture of substantial numbers of recruits who entered service after the 'prior year's' influenza vaccine was removed from use, but prior to the 'next year's' vaccine hav- ing become available. If these recruits had not been targeted for 'catch up' with the current year's vaccine, they would have remained unimmunized against influenza throughout their BCT period.

Another potential limitation in the interpretation of the results of the current study is related to the ecologic nature of the BPG prophylaxis assessment. BPG prophylaxis status was based on installation policy, not on individual record. Therefore, true GASillness cases may have been excluded from the study by the 30-day latency case-definition criterion. Furthermore, tandem prophylaxis with BPG not only protects recipients from acquiring GAS infections during the first few weeks of training but also prevents the seeding of GAS strains into the recruit population. To the extent that recruit camps are epidemiologically closed - hence, isolated from outside sources of GAS - tandem prophylaxis would lower risk of streptococcal illnesses during the entire basic training period. If trainees who received influenza immunizations were more likely than others to receive BPG, then the apparent association between influenza immunization and GAS-related illnesses could reflect he prolonged, population-level effects of tandem BPG prophylaxis [20]. However, there was no reason to have expected an association between BPG prophylaxis and influenza immunization. Furthermore, it is presumed that stratification by UIC would accommodate this association had it been extant.

In conclusion, the strong protective effect of Army trainee influenza immunization on the odds of GAS-illness diagnosis, measured in the current study, is both biologically plausible and relevant to current clinical military practice. Many epidemiologic and clinical interactions have been documented between respiratory pathogens-including, for example, between influenza and GAS $[5,8]$. Given this synergism among various pathogens, the effects of agent-specific interventions may also be synergistic (i.e., greater in scope and magnitude than preventing agent-specific diseases alone) [8]. A prospective study with immunization status verification and laboratory confirmed GAS-illness diagnosis is necessary to validate or refute these findings.

\section{References}

[1] Bisno AL, Peter GS, Kaplan EL. Diagnosis of strep throat in adults: are clinical criteria really good enough? Clin Infect Dis 2002;35:126-9.

[2] Denny Jr FW. A 45-year perspective on the streptococcus and rheumatic fever: the Edward H. Kass Lecture in infectious disease history. Clin Infect Dis $1994 ; 19(6): 1110-22$.

[3] Thomas RJ, Conwill DE, Morton DE, Brooks TJ, Holmes CK, Mahaffey WB. Penicillin prophylaxis for streptococcal infections in United States Navy and Marine Corps recruit camps, 1951-1985. Rev Infect Dis 1988;10(1):125-30.

[4] Brundage JF, Gunzenhauser JD, Longfield JN, Rubertone MV, Ludwig SL, Rubin FA, et al. Epidemiology and control of acute respiratory diseases with emphasis on group A beta-hemolytic streptococcus: a decade of U.S. Army experience. Pediatrics 1996;97(6 Pt 2):964-70.

[5] Brundage JF. Interactions between influenza and bacterial respiratory pathogens: implications for pandemic preparedness. Lancet Infect Dis 2006;6: 303-12.

[6] Peltola VT, Murti KG, McCullers JA. Influenza virus neuraminidase contributes to secondary bacterial pneumonia. J Infect Dis 2005;192:249-57.

[7] Hament JM, Kimpen JL, Fleer A, Wolfs TF. Respiratory viral infection predisposing for bacterial disease: a concise review. FEMS Immunol Med Microbiol 1999;26(3-4):189-95.

[8] Babiuk LA, Lawman MJ, Ohmann HB. Viral-bacterial synergistic interaction in respiratory disease. Adv Virus Res 1988;35:219-49.

[9] Rubertone MV, Brundage JF. The defense medical surveillance system and the department of defense serum repository: glimpses of the future of public health surveillance. Am J Pub Health 2002;92(12):1900-4.

[10] Chancey RL, Morris AJ, Conner RH, Catanzaro FJ, Chamovitz R, Rammelkamp $\mathrm{CH}$. Studies of streptococcal prophylaxis comparison of oral penicillin and benzathine penicillin. Am J Med Sci 1955;229(2):165-71.

[11] Bass JW, Longfield JN, Jones RG, Hartmann RM. Serum levels of penicillin in basic trainees in the U.S. Army who received intramuscular penicillin $\mathrm{G}$ benzathine. Clin Infect Dis 1996;22:727-8.

[12] Centers for Disease Control and Prevention. Key facts about influenza and the influenza vaccine. Accessed 22 August 2007. Available from: http://www. cdc.gov/flu/keyfacts.htm. 
[13] Kaul R, McGeer A, Low DE, Green K, Schwartz B. Population-based surveillance for group A streptococcal necrotizing fasciitis: clinical features, prognostic indicators, and microbiologic analysis of seventy-seven cases. Am J Med 1997;103(1):18-24.

[14] Lemon HM, Wise H, Hamburger M. Bacterial content of air in Army barracks. War Med 1944;6:92-101.

[15] Peters JE, Gackstetter GD. Streptococcus pyogenes transmission among Air Force recruits: efficacy of surveillance and prophylaxis protocols. Mil Med 1998;163(10):667-71.

[16] McNeill KM, Vaughn BL, Brundage MB, Li Y, Poropatich RK, Gaydos JC. Clinical presentations for influenza and influenza-like illness in young, immunized soldiers. Mil Med 2005;170(1):94-7.
[17] Hofer C, Binns HJ, Tanz RR. Strategies for managing group A streptococcal pharyngitis: a survey of board-certified pediatricians. Arch Pediatr Adolesc Med 1997; 151:824-9.

[18] Needham CA, McPherson KA, Webb KH. Streptococcal pharyngitis: impact of a high-sensitivity antigen test on physician outcome. J Clin Microbiol 1998;36(12):3468-73.

[19] Department of the Army. AR 40-562. Immunizations and Chemoprophylaxis September 29, 2006.

[20] Gunzenhauser JD, Brundage JF, McNeil JG, Miller RN. Broad and persistent effects of benzathine penicillin $G$ in the prevention of febrile acute respiratory disease. J Infect Dis 1992;166:365-73. 